\title{
STUDY OF BIOLOGICAL ACTIVITY AND CHEMICAL CONSTITUENT OF ANNONA RETICULATA
}

\section{Bimala Subba and Pramod Aryal}

Journal of Institute of Science and Technology

Volume 21, Issue 1, August 2016

ISSN: 2469-9062 (print), 2467-9240(e)

Editors:

Prof. Dr. Kumar Sapkota

Prof. Dr. Armila Rajbhandari

Assoc. Prof. Dr. Gopi Chandra Kaphle

JIST, 21 (1), 157-163 (2016)

Published by:

Institute of Science and Technology

Tribhuvan University

Kirtipur, Kathmandu, Nepal

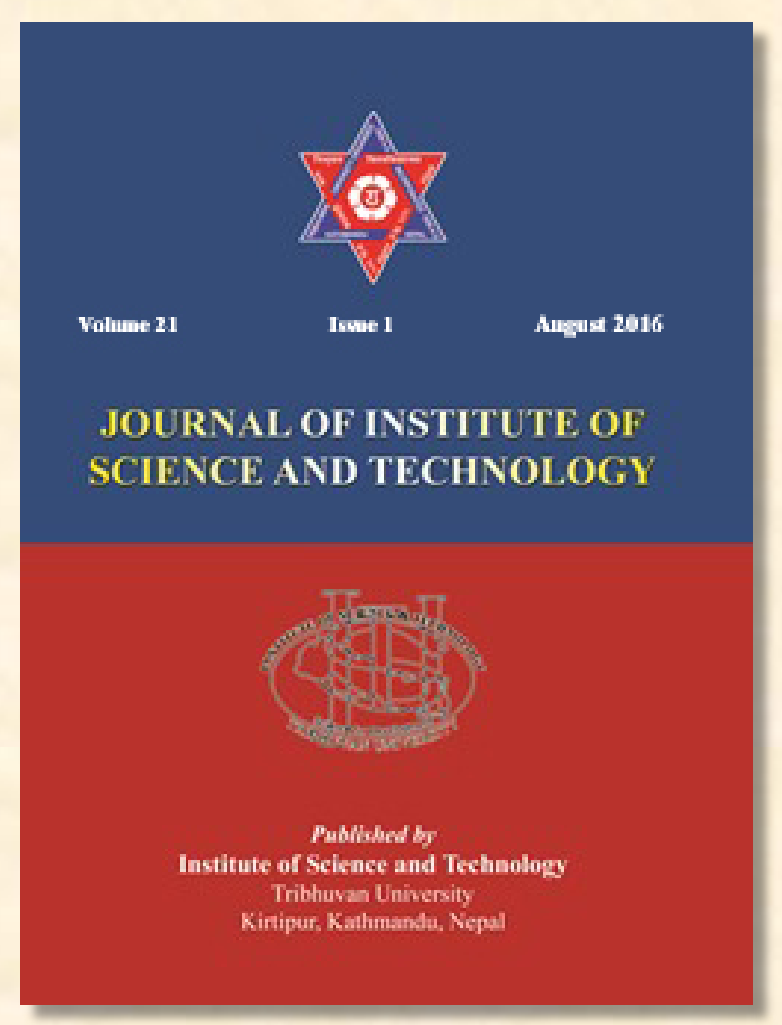




\title{
STUDY OF BIOLOGICAL ACTIVITY AND CHEMICAL CONSTITUENT OF ANNONA RETICULATA
}

\author{
Bimala Subba* and Pramod Aryal \\ Central Department of Chemistry, Tribhuvan University, Kirtipur, Nepal \\ ${ }^{*}$ Corresponding email: bimalasubba@gmail.com
}

\begin{abstract}
The methanol and hexane extract of leaf of Annona reticulata, vernacularly known as 'Sareefa' were subjected to biological assay and column chromatography respectively. Column chromatography of the hexane extract of the leaf of $A$. reticulata resulted in the isolation of one pure compound $\mathrm{PF}_{1}$. The compound PF1 was suggested as $\beta$-sitosterol by comparing TLC, IR and melting point with authentic sample. The antibacterial activity against two bacteria, Staphylococcus aureus (gram positive) and Escherichia coli (gram negative) was done by agar well diffusion method and Zone of Inhibition (ZOI) was observed. The ZOI obtained ranged from 8 to $12 \mathrm{~mm}$. The methanol extract of leaf showed moderate antibacterial activity on comparison with standard antibiotic streptomycin. The Antioxidant activity of the extract was tested using scavenging activity of DPPH (1, 1-Diphenyl-2- Picrylhydrazyl) radical method. The $\mathrm{IC}_{50}$ value of $A$. reticulata was found $(41 \mu \mathrm{g} / \mathrm{ml})$. The standard compound has shown $\mathrm{IC}_{50}$ value as $120 \mu \mathrm{g} / \mathrm{ml}$. The antimicrobial and antioxidant activity of the extract was positively associated with the total phenolic and flavonoid contents of the extract. This study revealed that methanolic leaf extract of A. reticulata comprise effective potential source of natural antioxidant, which might be helpful in preventing the progress of various oxidative stresses.
\end{abstract}

Keywords: Annona reticulata, Column Chromatography, $\beta$-sitosterol, Antioxidant, Antimicrobial, Phytochemicals

\section{INTRODUCTION}

Many plants are used in traditional system of medicine in Nepal (Manandhar 1986, 2000, Baral \& Kurmi 2006, Bhattarai 1989). Traditional medicine has a key role in the maintenance of health worldwide. Nowadays, there is a growing interest in the pharmacological evaluation of various plants used in traditional system of medicine in Nepal (Sharma et al. 2015, Subba \& Basnet 2014). Medicinal plants typically contain mixtures of different phytochemicals that may work individually, additively or in synergy to improve health. Annona reticulata belonging to family Annonaceae is commonly found in South Asia and originates from the West Indies and South America. It is mainly grown in gardens for its fruits and ornamental value. It is known as custard apple, sugar apple, sweet apple in English and Ramphal in Nepali (Chavan et al. 2014).The ethanobotanical survey and literature surveys revealed that $A$. reticulata is multipurpose tree with traditional uses as an antioxidant, antidiabetics, hepatoprotective, cytotoxic activity, genetoxicity, antitumor activity, antilice agent, vermifuges, anti inflammatory agent, wound healing, anti-malarial agent, as diarrhea and dysentery, anti-anxiety, anti stress, anti mutagenic, spasmolytic agent, positive chronotropic agent (Satyanarayana \& Gangarao 2013, Kirtikar \& Basu 1987). Different extract of $A$. reticulata contains different compound. The compound which is common in all Annona species is annonatin. Compound present in different parts of plant and in different extract, such as hexane extract, ethanol extract, GC-MS of methanolic extract has been reported. But biological activity and chemical constituent of $A$. reticulata of Makwanpur District, Nepal has not been reported yet. It is well known that the constituents of medicinal plants can vary greatly as a result of genetic factors, climate, soil quality and other external factors (Kaura et al. 1998, Kaushik et al. 2007). Thus, the present study deals with the study of biological activity on methanol extract and the chemical constituent analysis in hexane extract of $A$. reticulata collected from Makwanpur District of Nepal. 


\section{EXPERIMENTAL METHODS}

\section{Collection of Plants}

The leaves of $A$. reticulata were collected from Bhutandevi temple side, Makwanpur District of Nepal. The plant was identified comparing with authentic herbarium from Central Department of Botany, Tribhuvan University, Kirtipur, Kathmandu, Nepal. The collected leaves were washed with water, shade dried and powdered in grinding machine. The powder was stored in dry place until used for further experiment.

\section{Phytochemical Screening}

The phytochemical screening was carried out according to the procedure given by Ciulei (1982). In this process the presence of main groups of natural constituents in different extracts is analyzed by using different reagents. The different phytochemicals in the various extracts were identified by the color reaction with different reagents.

\section{Extraction}

$100 \mathrm{gm}$ of leaf of A. reticulata was completely extracted by percolation methods using hexane as a solvent at room temperature to obtain hexane extract. Similarly, $100 \mathrm{gm}$ of leaf of $A$. reticulata was also completely extracted by percolation methods using methanol as a solvent at room temperature to obtain methanol extract. The extract was concentrated under reduced pressure using a rotary evaporator and then stored in an air tight container for further study.

\section{Chemicals}

The chemicals used were methanol (Merck, Germany), DPPH and Ascorbic acid (Sigma Aldrich, USA). All other chemicals used were of the highest commercially available grade. Melting points were determined by using melting point apparatus from Griffin and George Company Limited (UK). Column chromatography was performed using silica gel of mesh no. 60-120. For thin layer chromatography "Silica gel-G" was used.

\section{Total Phenolic content}

The total phenolic content of methanolic extract of leaf of A. reticulata was determined using the Folin-Ciocalteu phenol reagent with slight modification. First $0.1 \mathrm{ml}$ of extract $(2.5 \mathrm{mg} / \mathrm{ml})$ was separately mixed with $1 \mathrm{ml}$ of Folin-Ciocalteu phenol reagent (1:10 dilution with the distilled water) and $0.8 \mathrm{ml}$ of aqueous $1 \mathrm{M} \mathrm{Na}_{2} \mathrm{CO}_{3}$ solution (Chang et al. 2002). The reaction mixture was allowed to stand for about 15 minutes and the absorbance of the reactants was measured at 765 $\mathrm{nm}$ using the UV-visible spectrophotometer. The calibration curve was obtained using the solution of gallic acid as standard in methanol and water $(50: 50 \mathrm{v} / \mathrm{v})$ using the concentration ranging from $10-100 \mu \mathrm{g} / \mathrm{ml}$ (Fig. 1). Based on this standard graph, the concentration of the sample was calculated. The total polyphenol content was expressed in terms of the milligrams of the gallic acid equivalent per gram of the dry mass (mg GAE $\left.\mathrm{g}^{-1}\right) . \mathrm{y}=0.010 \mathrm{x}$ with $\mathrm{R}^{2} 0.981$.

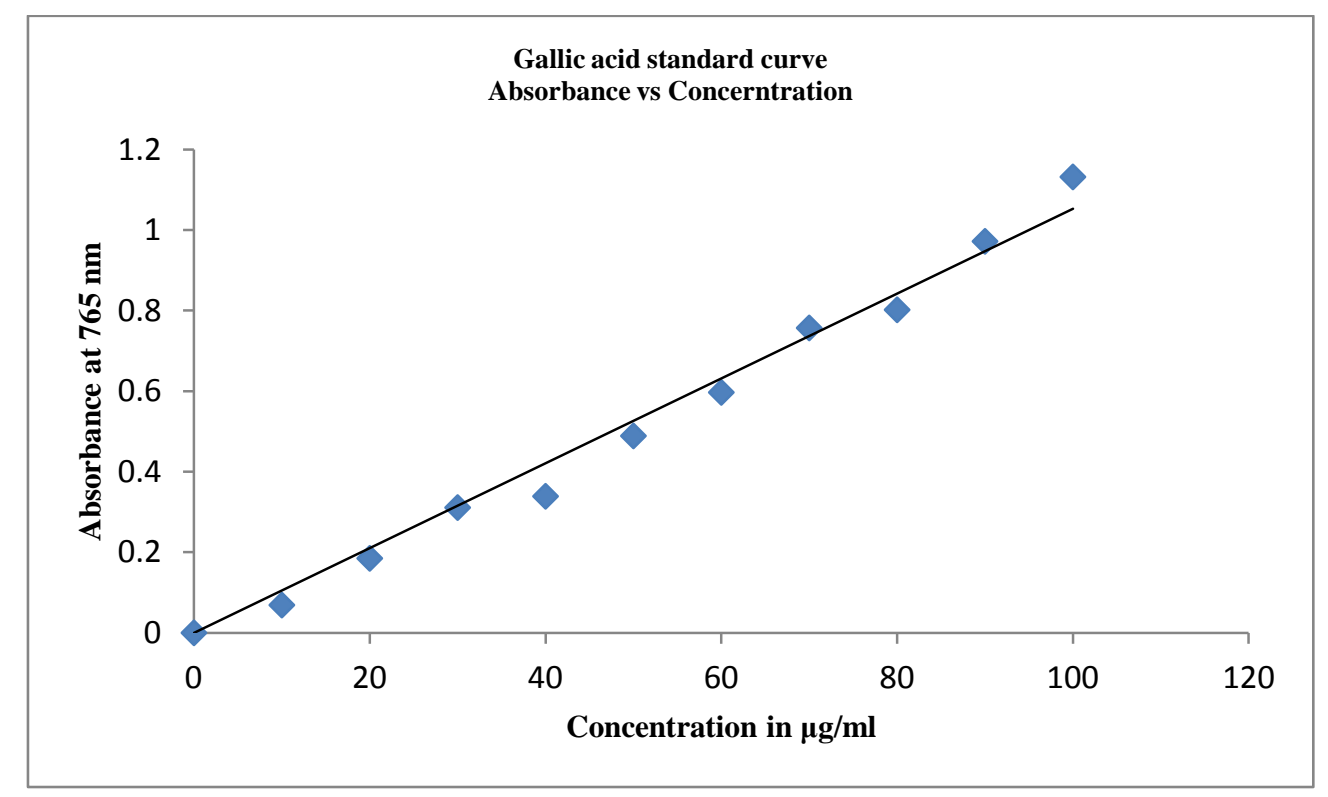

Fig. 1. Gallic acid standard curve. 


\section{Total flavonoids content estimation}

The total flavonoid content in the plant extract was estimated using the Aluminium chloride $\left(\mathrm{AlCl}_{3}\right)$ colorimetric method with slight modifications. 0.25 $\mathrm{ml}$ of extract $(10 \mathrm{mg} / \mathrm{ml})$ was mixed with the 0.75 $\mathrm{ml}$ of methanol, $0.05 \mathrm{ml}$ of the $10 \%$ aluminum chloride, $0.05 \mathrm{ml}$ of the $1 \mathrm{M}$ potassium acetate $\left(\mathrm{CH}_{3} \mathrm{COOK}\right)$ and $1.4 \mathrm{ml}$ of the distilled water. The reaction mixture was allowed to stand for about 30 minutes in room temperature. The absorbance of the mixture was measured at $415 \mathrm{~nm}$ using the UVvisible spectrophotometer (Thermo Fisher Scientific, Genesystem-10-5). The calibration curve was obtained with the help of the quercetin (Sigma) standard solutions in methanol with the concentration ranging from the $10-100 \mu \mathrm{g} / \mathrm{ml}$ (Fig. 2). The total flavonoid content was expressed in terms of the milligram of quercetin equivalent per gram of the dry mass $(\mathrm{mg} \mathrm{QE} / \mathrm{g}$ ) (Kalita et al. 2013).

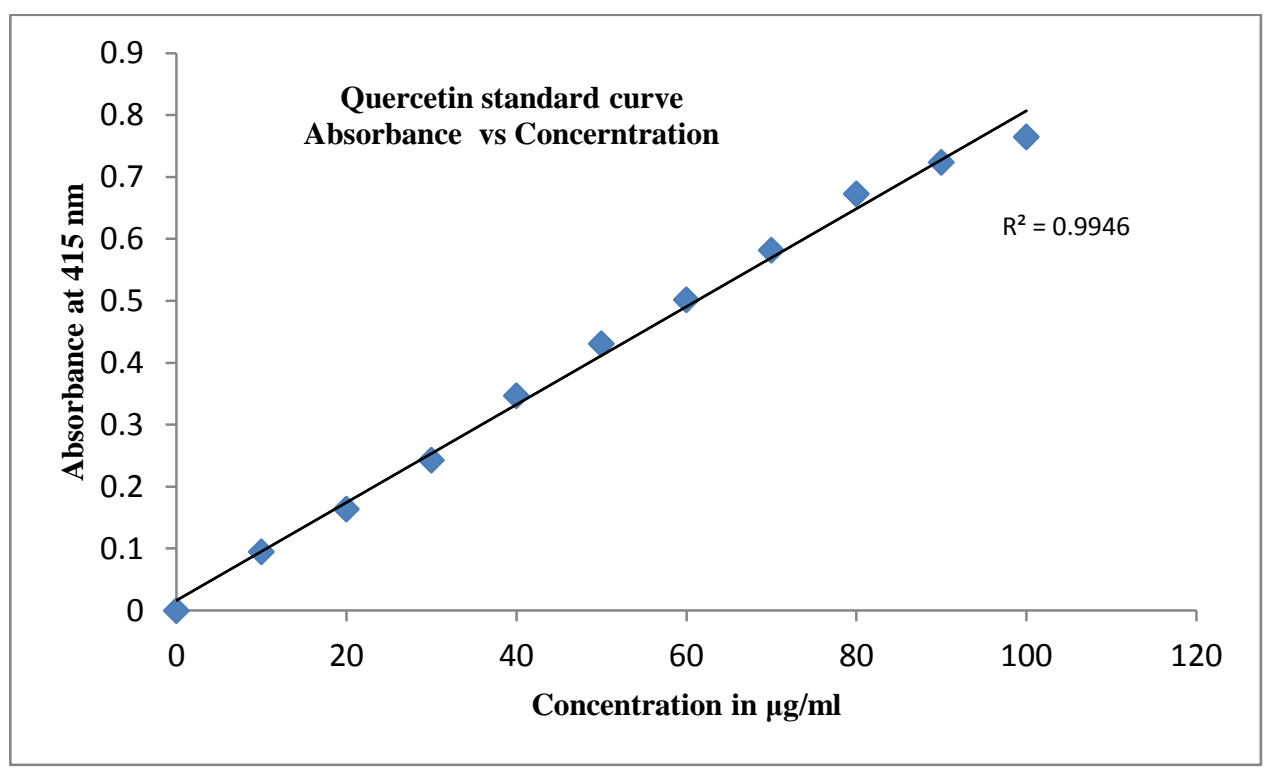

Fig. 2. Quercetin standard curve.

\section{Antibacterial assay}

The antibacterial assay of plant extracts was carried by using Agar well diffusion method based on the procedure given by Dingle et al. (1953). The wells were made in the incubated media plates with the help of sterile cork borer $(6 \mathrm{~mm})$ and labeled properly. Then $50 \mu \mathrm{l}$ of the working solution of the extract were loaded into the respective wells with the help of micropipette. The solvent (DMSO + water) was tested for its activity as a control at the same time in the separate well. The plates were then left for half an hour with the lid closed so that extracts diffused to the media. The plates were incubated overnight at $37^{\circ} \mathrm{C}$.

The microorganisms ( $S$. aureus and E. coli) used in this study were identified strains obtained from Central Department of Microbiology, TU, Nepal.

\section{Antioxidant activity \\ DPPH radical scavenging activity (RSA) assay}

The free radical scavenging activity of sample and standard ascorbic acid solution in methanol was determined based on their ability to react with stable 1, 1-diphenyl-2-picrylhyrazyl (DPPH) free radical (Blois 1958, Brand-williams et al. 2002). The plant sample at various concentrations (15-250 $\mu \mathrm{g} / \mathrm{ml}$ ) was added to a $100 \mu \mathrm{M}$ solution of DPPH in methanol. After incubation at $37^{\circ} \mathrm{C}$ for $30 \mathrm{~min}$, the absorbance of each solution was determined at 517 $\mathrm{nm}$. The measurement was performed in triplicates. The antioxidant activity of the sample was expressed as $\mathrm{IC}_{50}$ (inhibitory concentration), which was defined as the concentration (in $\mu \mathrm{g} / \mathrm{ml}$ ) of sample required to inhibit the formation of DPPH radicals by $50 \%$. Ascorbic acid was used as positive control. Free radical scavenging activity was calculated by using following equation:

$\%$ of free radical scavenging activity $=\left(\mathbf{A}_{\mathbf{0}}-\mathbf{A}_{\mathbf{T}}\right) \times \mathbf{1 0 0}$ $\mathbf{A}_{0}$

Where, $\mathrm{A}_{\mathrm{O}}=$ Absorbance of DPPH solution and $\mathrm{A}_{\mathrm{T}}$ $=$ Absorbance of test or reference sample. The \% scavenging was then plotted against concentrations used and from the graph $\mathrm{IC}_{50}$ was calculated. 


\section{Statistics}

All the analysis was carried out in triplicate and the results are expressed as mean $+\mathrm{SD}$.

Separation of compounds by the use of column chromatography

The hexane extract (25.015 gm) was adsorbed on $22 \mathrm{gm}$ of silica gel and loaded on to a silica gel (125 gm, E-merck, 60-120 mesh) packed in the column having internal diameter $3 \mathrm{~cm}$ with the adsorbent height $42 \mathrm{~cm}$. The column was eluted with different fractions of hexane, ethyl acetate and methanol to obtain a number of fractions (Data not shown).

\section{Isolation and Characterization of Compounds Compound $\mathbf{P F}_{\mathbf{1}}$}

Fractions 41-44, eluted with 5\% EtOAc in hexane, were mixed and concentrated using rotary evaporator. The obtained residue was further washed with methanol for several times and recrystallized with 1:1 ethyl acetate: hexane for three times. Then purified compound were checked by TLC and further confirmed by Co-TLC with authentic sample, melting point, IR and NMR.

\section{RESULTS}

Phytochemical Screening The phytochemical screening of methanol extract of the plant showed the presence of secondary metabolites such as polyphenols, reducing compounds, alkaloids, glycosides, flavonoids, quinones, steroids, saponins and coumarin derivatives.

\section{Antibacterial Activity}

The antibacterial activity of methanol extract of $A$. reticulata leaf is presented in Table 1. The extract has shown moderate activity in dose dependent manner with tested bacteria on comparison to standard antibiotic (Streptomycin) Table 2.

Table 1: Mean Zone of inhibition (ZOI) shown by methanol leaves extract of $A$. reticulata against tested bacteria.

\begin{tabular}{|c|c|c|c|c|}
\hline \multirow{3}{*}{$\begin{array}{l}\text { Bacterial } \\
\text { Species }\end{array}$} & \multicolumn{4}{|c|}{ (Zone of inhibition in $\mathbf{m m}$ ) } \\
\hline & \multicolumn{4}{|c|}{ Concentration of Plant Extract } \\
\hline & $0.25 \mathrm{mg} / \mathrm{well}$ & $0.1 \mathrm{mg} /$ well & $1.25 \mathrm{mg} /$ well & $2.5 \mathrm{mg} / \mathrm{well}$ \\
\hline S. aureus & 8 & 9 & 10 & 12 \\
\hline E. coli & 9 & 10 & 10 & 11 \\
\hline
\end{tabular}

Table 2: Mean Zone of inhibition (ZOI) shown by different concentrations of streptomycin against tested bacteria

\begin{tabular}{|l|l|l|l|l|}
\hline \multirow{2}{*}{$\begin{array}{l}\text { Bacterial } \\
\text { Species }\end{array}$} & \multicolumn{4}{|c|}{ (Zone of inhibition in mm) } \\
\cline { 2 - 5 } & \multicolumn{4}{|c|}{ Concentration of Standard antibiotic (Streptomycin) } \\
\cline { 2 - 5 } & $\mathbf{0 . 2 5} \mathbf{~ m g / w e l l ~}$ & $\mathbf{0 . 1} \mathbf{~ m g / w e l l ~}$ & $\mathbf{1 . 2 5} \mathbf{~ m g / w e l l}$ & $\mathbf{2 . 5} \mathbf{~ m g / w e l l ~}$ \\
\hline S. aureus & 16 & 18 & 21 & 29 \\
\hline E. coli & 16 & 21 & 24 & 25 \\
\hline
\end{tabular}

Total phenolic and flavonoids contents

Total phenolic content was estimated by using Folin-Ciocalteu reagent. Total phenolic content of the methnol extract of $A$. reticulata leaf was found to be $135.52 \pm 7.15 \mathrm{mg} / \mathrm{g}$ expressed as gallic acid equivalent (GAE). The total flavonoid content in the fractions was expressed as $\mu \mathrm{g}$ quercetin equivalent. The content of total flavonoids was found $331.165 \pm 5.565 \mathrm{mg}$ Quer/ mg.

\section{Antioxidant}

The methanol extracts of $A$. reticulata leaf showed potential free radical scavenging activity having an $\mathrm{IC}_{50}$ value of $51.29 \pm 10.94 \mu \mathrm{g} / \mathrm{ml}$ (Fig. 3). On the other hand the free radical scavenging activity of standard (ascorbic acid) was having an $\mathrm{IC}_{50}$ value of $12.5 \mu \mathrm{g} / \mathrm{ml}$ (Fig. 4). 


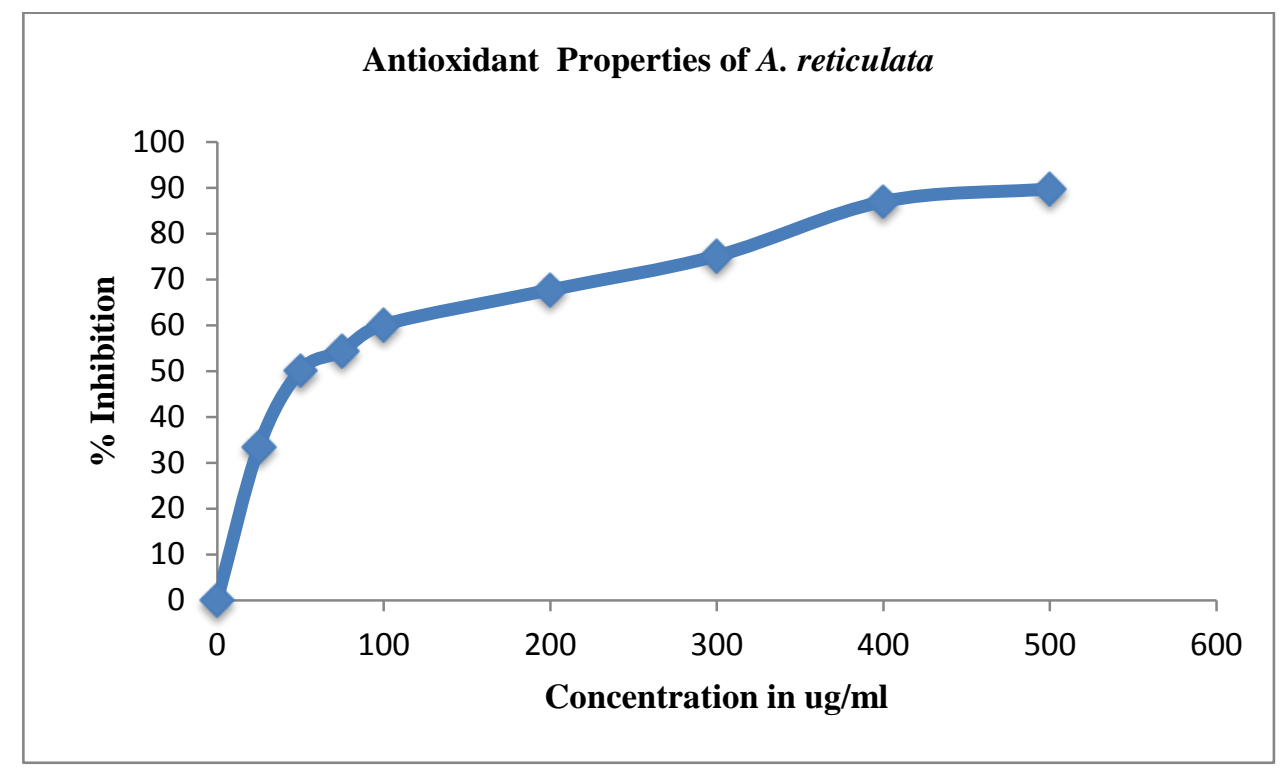

Fig.3. Graph of \% inhibition versus concentration of A. reticulata.

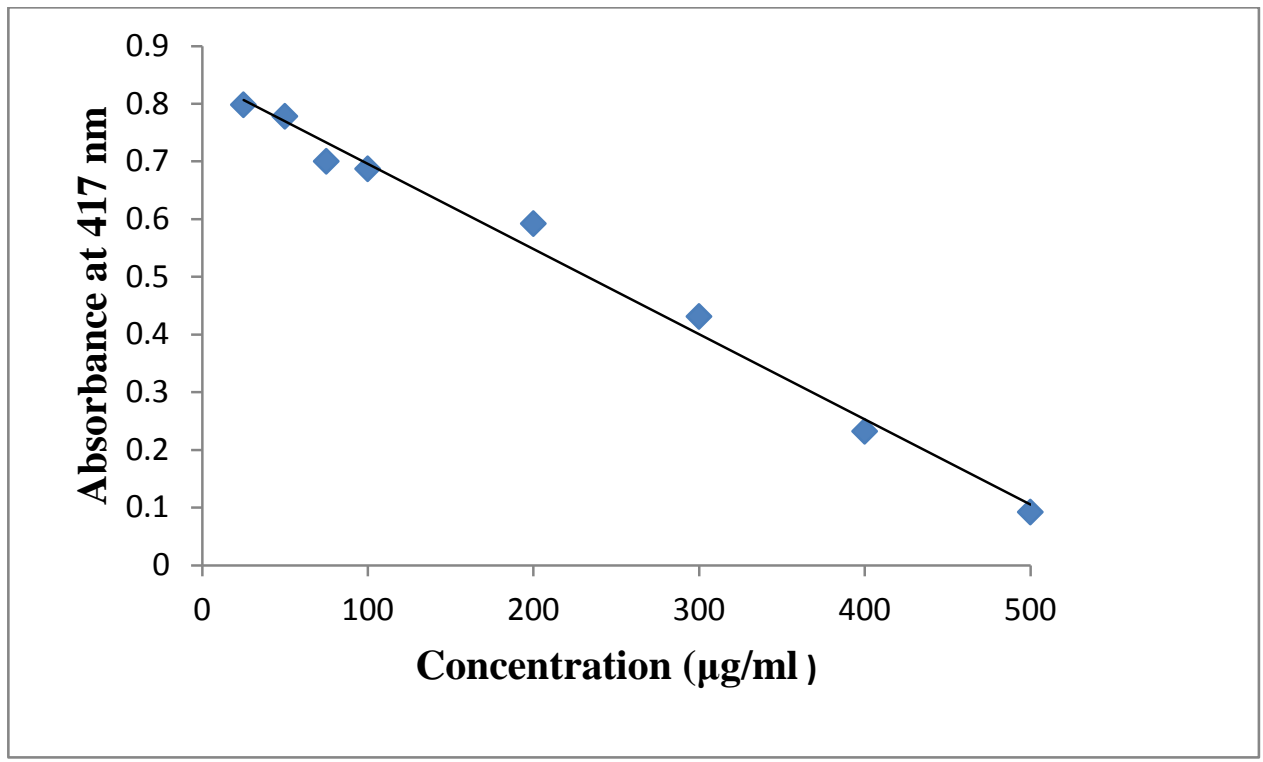

Fig 4. Graph Absorbance versus Concentration of Ascorbic acid.

\section{Compound $1\left(\mathrm{PF}_{1}\right)$}

Compound $\mathrm{PF}_{1}$ represented the white needle shaped crystalline compound. The compound gave single spot with $20 \%$ EtOAc in hexane in TLC with $\mathrm{R}_{\mathrm{f}}$ value 0.45 . The melting point was found to be 134 ${ }^{\circ} \mathrm{C}$. It gave greenish red color (positive test) in Liebermann-Burchard test which indicates the compound to be Sterol.

The IR spectrum showed presence of $-\mathrm{OH}$ group $\left(3433 \mathrm{~cm}^{-1}\right)$. Similarly, the absorption bands at $2939.52 \mathrm{~cm}^{-1}$ and $1373.32 \mathrm{~cm}^{-1}$ were due to $-\mathrm{C}$ $\mathrm{H}$ stretching and bending respectively. A peak at
$1018 \mathrm{~cm}^{-1}$ showed the presence of $-\mathrm{C}-\mathrm{O}$ group. Moreover, a peak at $2870.08 \mathrm{~cm}^{-1}$ represented the $-\mathrm{C}-\mathrm{H}$ stretching band of $-\mathrm{C}=\mathrm{C}-\mathrm{H}$ group and peak at $1666.50 \mathrm{~cm}^{-1}$ represented $\mathrm{C}=\mathrm{C}$ absorption peak (Data not shown) (Silverstein \& Webster 2007). The melting point of the compound was found to be $133{ }^{\circ} \mathrm{C}$. The compound was further confirmed by Co-TLC with authentic sample, IR and proton NMR (Data not shown). From all the comparative analysis, the compound was proposed to be $\beta$ - sitosterol (Fig. 5). 


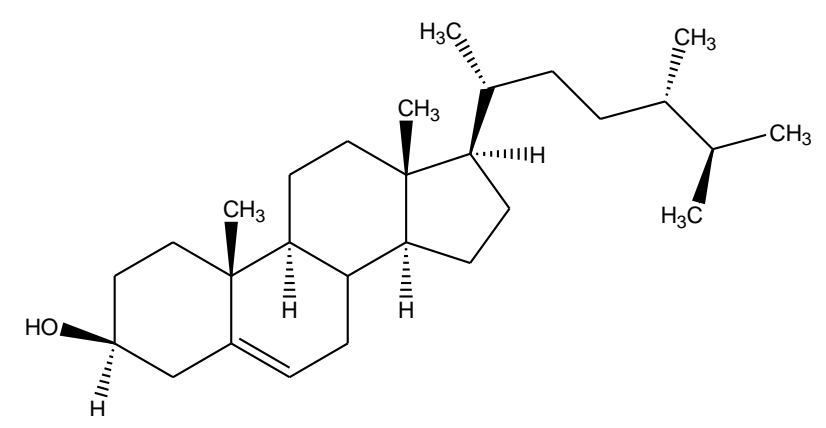

Fig. 5. $\beta$ - Sitosterol

\section{DISCUSSION}

The result of phytochemical analysis revealed the presence of polyphenols, reducing compounds and other. It is reported that the phenolic compounds constitute a major group of phytochemicals that acts as primary antioxidants (Hatano et al. 1989). The total phenolic content of $A$. reticulata extract in terms of gallic acid equivalent (GAE) is indicative of high antioxidant potential of the extract, because the phenolic constituents can react with active oxygen radicals such as hydroxyl radical (Hussein et al. 1987), superoxide anion radical (Afanaslev et al. 1989) and lipid peroxy radical (Torel et al. 1986). Literature reports showed that there is high correlation between antioxidant activity and phenolic compounds (Odabasoglu et al. 2004). In view of the fact that A. reticulate leaf possesses good phenolic and flavonoid content, it could be assumed that it can have a higher free radical scavenging activity. A positive correlation between antioxidant activity and polyphenol content was found here, suggesting that the antioxidant capacity of the plant extracts is due to a great extent to their polyphenols and flavonoids.

Similarly it has been reported that antimicrobial activities of plant extract also correlated well with their phenolic fraction. Antimicrobial activities of the bioactive compounds such as phenolics and organic acids have indeed reported against human pathogens e.g Salmonella and Staphylococcus (Puupponen-Pimia et al. 2005). In the present study methanol extracts of $A$. reticulata leaf has been tested against drug resistant and human pathogenic bacteria E. coli and S. aureus. The result obtained here are in good agreement with previously reported data Jansi et al. (2013). Strong antimicrobial activity has been reported. $\beta-$ sitosterol was suggested to be present in fractions 41-44 of 5\% EtOAC in hexane eluted from column chromatography of hexane extract of A. reticulata.

\section{CONCLUSIONS}

The results obtained from this study indicate that leaves of $A$. reticulata possess antioxidant properties and could serve as free radical inhibitors or scavenger, or acting possibly as primary antioxidants. The antibacterial activities of $A$. reticulata leaves are not efficient as standard Sterptomycin, the microorganism become resistant to offered antibiotic over time. Again, of recent, a lot of attention is being committed to sources of natural antioxidant and antibacterial agents, the data obtained in this study might suggest a possible use of $A$. reticulata leaves as source of natural antioxidant and antibacterial agents. Furthermore, detailed studies on the isolation and characterization of the plant extract as well as in vivo assays will be needed in discovering new biological antioxidants and antibacterial agents.

\section{ACKNOWLEDGEMENTS}

The authors are thankful to Central Department of Chemistry, Tribhuvan University, Kirtipur, Nepal for providing us the research facilities to conduct this research work and Central Department of Biotechnology, Tribhuvan University, Kirtipur, Nepal for providing us the facilities to conduct antibacterial assay.

\section{REFERENCES}

Afanaslev, I. B., Dorozhko, A. I. and Bordskii, A. V. 1989. Chelating and free radical scavenging mechanisms of inhibitory action of rutin and quercetin in lipid peroxidation. Biochemical and Pharmacology. 38:1763-1769.

Baral, S. R and Kurmi, P. P. 2006. A compendium of medicinal plants in Nepal. Publisher: Mrs Rachana Sharma, Printed in Nepal by Mass Printing Press, Kathmandu, Nepal, pp.534.

Bhattarai, N. K. 1989. Traditional Phytotherapy among the Sherpa of Helambu in Central Nepal. Journal of Ethnopharmacology 129 (3): 203-209.

Blois, M.S. 1958. Antioxidant determinations by the use of a stable free radical. Nature, 26:1199-1200.

Brand-williams, W. Cuvelier, M. E. and Berset C. 1995.Use of a free radical method to evaluate antioxidant activity. Food Science and Technology 28:25-30.

Chang, C., Yang, M., Wen, H. and Chern, J. 2002. Estimation of total flavonoids content in propolis by two complementary colorimetric 
methods. Journal Food Drug Analysis. 10: 178-182.

Chavan, S. S., Shamkumar P. B., Damale M. G. and Pawar D. P. 2014. A comprehensive review on annona reticulate. International Journal of Pharmaceutical Sciences and Research, 5(1): 45-50.

Cheng, C., Yang, M., Wen H. and Chern J. 2002. Estimation of total flavonoid content in propolis by two complementary colorimetric methods. Journal of Food and Drug Analysis, 10(3): 178-182.

Culie, I. 1982. Methodology for analysis of vegetable drugs, Practical manuals on industrial utilization of medicinal and aromatic plant, Bucharest. Phytochemistry, 63: 97-104.

Dingle, J., Reed, W. W. and Solomons, G. L. 1953. The enzymatic degradation of pectin and other polysaccharides, applications of the cup assay method to the estimation of enzyme. Journal of Science, Food and Agriculture, 40: $149-153$.

Hatano, T., Edamatsu, R., Mori, A., Fujita, Y., Yasuhara, T., Yoshida, T., et al. 1989. Effects of the interaction of tannins with coexisting substances. VI. Effects of tannins and related polyphenols on superoxide anion radical, and on 1,1-diphenyl-2-picrylhydrazyl radical. Chemical and Pharmaceutical Bulletein (Tokyo), 37: 2016-2021.

Jansi, R., Devi, R. and Vidyashri, M. 2013. Phytochemical Screening and Antimicrobial Activity of Various Solvent Extracts of Annona reticulate leaves. International Journal of Science Invention Today, 2(5), 347-358.

Kalita, P., Barman, T. K., Pal, T. K. and Kalita, R. 2013. Estimation of total flavonoids content (tfc) and anti oxidant activities of methanolic whole plant extract of Biophytum sensitivum linn. Journal of Drug Delivery and Therapeutics, 3(4), 33-37.

Kaura, S. K., Gupta, S. K. and Chowdhury, J. B. 1998. Morphological and oil content variation in seeds of Azadirachta indica A. Juss (Neem) from northern and western provenances of India. Department of Genetics, CCS Haryana Agricultural Univ. Hisar, India.

Kaushik, N., Gurudevsingh, B., Tomar, U. K., Naik, S. N., Satya, V., Bisla, S. S., et al.
2007. Regional and habitat variability in azadirachtin content of Indian Neem (Azadirachta indica A Juss.). Current Science, 92(10): 1400-1406.

Kirtikar, K. R. and Basu, B. D. 1987. Indian Medicinal Plants: International Book Distributers, Deharadun, India, 68-69.

Manandhar, N. P. 1986. Traditional Plants used by Cepang Tribals of Makwanpur District, Nepal. Fitoterapia 60(1):61-68.

Manandhar, N. P. 2000. Plants and People of Nepal. Timber Press, Oregon USA.

Odabasoglu, F., Aslan, A., Cakir, A., Suleyman, H. and Karagoz, Y. 2004. Comparison of antioxidant activity and total phenolic content of three lichen species. Phytotherapy Research. 18:938-941.

Puupponen-Pimia, R., Nohynek, L., Alakomi, H. L., and Oksman- Caldentey, K. M. 2005. Bioactive berry compounds-Novel tools against human pathogens: Mini- review. Applied Microbiology and Biotechnolog, 67: 8-18.

Satyanarayana, T. and Gangarao B. 2013. Pharmacognostical and phytochemical studies of annona reticulata linn International. Journal of Research In Pharmacy and Chemistry, 3(2): 477-482.

Sharma, K. R. Kalauni, S. K. Awale, S. and Pokharel, Y.R. 2015. In Vitro Free Radical Scavenging Activity of Methanol Extracts of Some Selected Medicinal Plants of Nepal. Austin Journal of Biotechnology \& Bioengineering 2(1): 1035.

Silverstein, R. M. and Webster, F. X. 2007. "Spectrometric Identification of Organic Compounds", sixth edition, Gopal Jee Enterprises, Delhi, India.

Sofowora, A. 1993. Medicinal plants and traditional medicine in Africa, Spectrum books Ltd., Ibadan, Nigeria, 191-289.

Subba, B. and Basnet, P. 2014. Antimicrobial Activity of Some Medicinal Plants from East and Central part of Nepal. International Journal of Applied Science and Biotechnology 2: 88-92.

Torel, J., Cillard, J. and Cillard, P. 1986. Antioxidant activity of flavonoids and reactivity with peroxy radicals. Phytochemistry, 25:383-385. 